\section{DE DE GRUYTER OPEN}

Przedsiębiorczość i Zarządzanie Entrepreneurship and Management University od Social Sciences Publishing House

ISSN 1733-2486

Volume XVI, Issue 2, pp. 111-119

DOI 10.1515/eam-2015-0020

Łukasz Sułkowski

University of Social Sciences

\title{
Management - from Epistemology by Methodology to Social Practice of Academia Cognitive Challenges in Management Science $\mathbf{2}^{1}$
}

\begin{abstract}
The aim of the article is to present cognitive challenges in the area of management. Researchers and reflective managers still work on the identity of management belonging to the social sciences. The paper depicts the connections between cognitive problems (from the epistemological point of view), management methodology and social practice. Management sciences are parts of historical discourse and because of that epistemological and methodological levels have an impact on social practice. The main concern of this paper is the role of the management scientist, consultant and teacher. The analysis suggests that academic teacher and researcher are social roles with a character that can be called universal. Practitioner is associated rather with pragmatic aspect of management science. Practitioners are often regarded as managers, but their roles in the organisation might as well be non-managerial.
\end{abstract}

Key words: epistemology, management methodology, management paradigms, social practice.

\footnotetext{
${ }^{1}$ The deeper analysis of the problem in: Ł. Sułkowski, Epistemology of Management, Peter Lang International, Frankfurt-Berlin-Bern-Vien-Oxford-New York-London-Warsaw, 2013.
} 


\section{Introduction}

Within management sciences one can identify various cognitive problems, which are situated on epistemological level, but influenced also methodologi$\mathrm{cal}$, pragmatic, and institutional levels. The rate of development of our sciences in the society, as well as of the role they play, depends on the effectiveness of coping with those problems.

This paper is the second publication from the series of three articles about cognitive challenges in management science. It is the result of the further discussions and reflections concerning the cognitive problems of management after publication about epistemology of management. The question of identity of management perceived like a social science is important mainly to researchers, but also to reflective managers. After considering the problem of 'permanent immaturity' of management sciences, another cognitively fundamental question is the relation between the theory and practice of management. The paper shows the transfer of the cognitive problems from the most general epistemological field, by methodology of management, just to social practice. The main concern of this paper is the role of the management scientist, consultant and teacher.

\section{Theory versus practice in management}

The main challenge, accompanying management science since its beginning, concerns the tension between theory and practice [Tranfield, Starkey 1998, pp. 341-353]. Apart from many problems of the relation between the theory and practice of management, I would like to focus on three important issues, which are as follows:

- position of researchers towards the problem of theory and practice of management,

- diversified approach to the relation between the theory and practice on the grounds of different paradigms of management,

- question of popularisation of the achievements of management sciences.

\section{Approach to the problem of the relation between the theory and practice of management}

In the area linking the theory of management with its practice the opinions of researchers are very diverse. We find both, the supporters of a very close relation between the management sciences with practice, as well as, on the opposite end of the continuum, the followers of dealing solely with the theory of 
management sciences, leaving the application to practitioners and consulting sector [Duncan 1974, pp. 724-738]. For example, among researchers studying the area of marketing, one can find supporters of the position that 'marketing' is primarily a management practice and not a scientific discipline [Figiel 2006, p. 36]. On the other hand, many researchers working on the theory of organisation limit themselves to abstract analyses, distancing from application problems [Hatch 2002].

\section{Theory vs. practice of management from the paradigmatic perspective}

In case of researchers working on the grounds of different paradigms of management, a slightly different approach to the problem of practical application of our discipline can be valuable. Using the distribution of paradigms referring to the matrix, developed by G. Burrell and G. Morgan [1979], which was later modified by me, it can be indicated that Critical Management Studies paradigm tends to involve, in principle, in the practice of management. One of the fundamental postulates of CMS is conducting emancipation activities towards disadvantaged groups, which is accompanied by demystification of the ideology of managerism [Sułkowski 2006]. However, after analyzing the literature of CMS, one can indeed find a lot of theoretical texts which do not touch the application problems of the described concepts.

\section{Popularisation of the achievements of management sciences}

The researchers in the management field very often try to popularize and organize the discipline. Such kind of pragmatism means that management science belongs to practical sciences and practical usefulness is of scientific value. Although paths of management theory and practice diverge increasingly [Micklewaith, Woolridge 1998, pp. 19-20]. The development of management theory is now an academic activity, promoted more and more often in academic literature, while practical achievements are still not estimated in a sufficient way. Due to the development of professionalization and specialisation, management science starts to be hermetic. It operates on systems of notions, language and values which are not easy to analyse not only for amateurs but also for researchers who are not academic ones. There is a need for the science popularisation, the most essential scientific findings could be presented to the readers, which allows people interested to choose concepts that would be worth deeper cognition and implementation. This popularisation may lead to the more complex theories which would end in social consciousness. But there is a thin line between popularisation and also vulgarisation of science, 
for example between the simplified essence of the presented theory and the deformation of its results. It can be observed that this line is crossed in various publications in the field of management and the rest of social sciences disciplines. We can give examples of publications, easy to access on the Internet and in bookshops, containing the knowledge on management that cannot be trusted. Authors present themselves as 'management gurus', with the aim to advertise their way of depicting things. They are not really gurus like Peter Drucker, Philip Kotler or Igor Ansoff who were known for combining popularisation with valuable theory. Besides, we have nowadays an advisory sector between the business sector and business schools, it uses academic work only to a certain extent. As a consequence, the level of division between theory and management practice grows bigger. Due to marketing reasons, the promoted advisory concepts are shown in an uncritical way which leads to lowering the authority of management science [Sułkowski 2012, pp. 13-23]. For instance, the thoughtless attitude to organizational culture, management values and reengineering and also using those concepts in an inappropriate way make the managers believe research environment would not be of any use and is not trustworthy [Strang, Macy 2001, pp. 147-182].

The researchers play the most important roles in the institutional structure of science, as they work on developing the discipline, as well as the academic teacher who transfer the knowledge to others. We cannot imagine management without practice, researchers and theoreticians often deal with business activities. The roles of practitioners are more visibly seen than in other social sciences. The borderline between consulting and scientific activity is not clear. Pragmatism requires organisational changes, created and implemented by researchers, and consultants focus on the knowledge about how the organization functions. The most popular concepts are evoked by authors that can be called "gurus". As long as the diversity of social roles and approaches of practitioners and theoreticians is to be concerned, we should analyse the questions about identity of teachers and researchers, which include:

1. destruction of good managerial practice by "pseudo-theories" of management "gurus" [Ghoshal 2005, pp. 75-91];

2. ideology and fashion in management;

3. split personality of researchers, practical and theoretical minds;

4. cultural and social conditions of the management researchers and specialists role;

5. the situation of researchers and specialists in our country, not forgetting about the position of Polish managers in the global world. 


\section{Role of management scientists}

F. Znaniecki depicted the division of the social roles of scientists: practitioners - specialists, scholars, explorers - researchers [Znaniecki 1984]. E. Gummson focuses on the social roles of researchers and gives descriptions which are gradual, from scientific work without anything else, through consulting, to management:

1. analyst - intellectual work in its pure form;

2. project participant - intellectual work in a team, in an organisation;

3. therapist/moderator - intellectual work with an attention paid to emotionality, cooperation, interpersonal relations;

4. organizational development (OD) consultant - combing intellectual work and being sensitive to interpersonal relations;

5. an agent of changes - work that is action-oriented;

6. external board director - oriented on action and decision-making but as well on knowledge and introducing changes;

7. manager-working in the organisation, emphasis on action [Gummson 1991, p. 39].

This division was to help to describe the levels of researchers involvement in an organisation. All of the roles can have practical and theoretical orientations (which is illustrated in table 1). All of them also require wide knowledge about how the organisation works, they can then use it for some scientific purposes. This means the link between researchers and practitioners: increasing theoretical knowledge and discovering more about the organisation. 
Table 1. Scientific and consulting roles

\begin{tabular}{|l|l|l|}
\hline \multicolumn{1}{|c|}{ Criteria } & \multicolumn{1}{|c|}{ Scientific roles } & \multicolumn{1}{c|}{ Consulting roles } \\
\hline $\begin{array}{l}\text { Identification } \\
\text { and identity }\end{array}$ & Scientific environment & $\begin{array}{l}\text { Managers, external board } \\
\text { directors }\end{array}$ \\
\hline Aims & $\begin{array}{l}\text { Getting knowledge, scientific } \\
\text { position (publications, quotes) }\end{array}$ & $\begin{array}{l}\text { Customer satisfaction, an image } \\
\text { that would lead to the position } \\
\text { on the market }\end{array}$ \\
\hline Research area & Related to research projects & $\begin{array}{l}\text { Thin chosen area of } \\
\text { organisational consultancy }\end{array}$ \\
\hline Perspective & $\begin{array}{l}\text { Focusing on the development } \\
\text { of theory, practice as a help } \\
\text { for the process of creating the } \\
\text { theory }\end{array}$ & $\begin{array}{l}\text { Practical orientation, theory } \\
\text { is be useful when it is used to } \\
\text { implement the practice }\end{array}$ \\
\hline Methods & $\begin{array}{l}\text { Cognitive effectiveness and } \\
\text { access to the study subject }\end{array}$ & Pragmatic effectiveness \\
\hline Quality & $\begin{array}{l}\text { Assessment of the quality of } \\
\text { research by the academic circles }\end{array}$ & $\begin{array}{l}\text { Assessment of the consultancy } \\
\text { quality by customers and the } \\
\text { market }\end{array}$ \\
\hline
\end{tabular}

Source: E. Gummson, Qualitative methods in management research, Newbury Park, Calif:: Sage Publications, 1991, p. 172.

Scientists in the field of management can be settled in different social roles, such as: practitioner, researcher, academic teacher and even so called 'guru'. Others are also possible, but these four would help to emphasise on the differences. Researchers treat the organisation as an object of cognition, while teachers find the transmission of knowledge valuable, and in the same time practitioners try to introduce some changes. Gurus focus on intuitive cognition which also may end in changes being made [Peters 1994]. The approach for the output of management, looking for certainty and orientation versus action also shows differences between the roles of scientists in the area of management. Researchers use the management output to put the emphasis on cognition and probable knowledge. The ethos of the researcher is of a value for them, and their readers are mostly from the academic environment. Academic teachers make the output popular, with the use of the canon of probable knowledge, but their main field of interest is not cognition but communication activities. They adopt the ethos of the teacher, and their audiences are most often students. Practitioners focus on activities, not always following 
the rules of management methodology. Similarly consultants, whose audience usually involve managers, employees and customers of an organisation.

Table 2. Social scientists' roles in the area of management

\begin{tabular}{|l|l|l|l|l|}
\hline \multicolumn{1}{|c|}{ Social role } & \multicolumn{1}{|c|}{ Researcher } & \multicolumn{1}{|c|}{ Teacher } & \multicolumn{1}{|c|}{ Practitioner } & \multicolumn{1}{|c|}{ Guru } \\
\hline Study subject & $\begin{array}{l}\text { Organisation } \\
\text { as a subject } \\
\text { of scientific } \\
\text { cognition (in } \\
\text { search for the } \\
\text { truth) }\end{array}$ & $\begin{array}{l}\text { Organisation } \\
\text { as a place } \\
\text { of the social } \\
\text { transmission of } \\
\text { knowledge }\end{array}$ & $\begin{array}{l}\text { Organisation } \\
\text { as a subject of } \\
\text { changes }\end{array}$ & $\begin{array}{l}\text { Organisation } \\
\text { as an object } \\
\text { of intuitive } \\
\text { cognition } \\
\text { and changes }\end{array}$ \\
\hline $\begin{array}{l}\text { Attitude } \\
\text { towards the } \\
\text { discipline } \\
\text { output }\end{array}$ & $\begin{array}{l}\text { Focusing on it } \\
\text { (theorising) }\end{array}$ & $\begin{array}{l}\text { Popularisation } \\
\text { of it }\end{array}$ & $\begin{array}{l}\text { Adaptation of } \\
\text { the pragmatic } \\
\text { methodology } \\
\text { of the } \\
\text { discipline }\end{array}$ & $\begin{array}{l}\text { A declaration } \\
\text { of rejecting it }\end{array}$ \\
\hline $\begin{array}{l}\text { Looking for } \\
\text { certainty }\end{array}$ & $\begin{array}{l}\text { Searching } \\
\text { for high } \\
\text { probability }\end{array}$ & $\begin{array}{l}\text { Searching for } \\
\text { the transmission } \\
\text { of the canon } \\
\text { of probable } \\
\text { knowledge }\end{array}$ & $\begin{array}{l}\text { Working in } \\
\text { uncertain } \\
\text { conditions }\end{array}$ & $\begin{array}{l}\text { A suggestion } \\
\text { of certainty }\end{array}$ \\
\hline $\begin{array}{l}\text { Cognition or } \\
\text { action }\end{array}$ & Cognition & Communication & Activities & Activities \\
\hline $\begin{array}{l}\text { Professional } \\
\text { ethos }\end{array}$ & $\begin{array}{l}\text { A scientist and } \\
\text { a researcher }\end{array}$ & $\begin{array}{l}\text { An academic } \\
\text { teacher }\end{array}$ & A consultant & $\begin{array}{l}\text { A witch } \\
\text { doctor and } \\
\text { a prophet }\end{array}$ \\
\hline Audience & $\begin{array}{l}\text { Scientific } \\
\text { environment }\end{array}$ & Students & $\begin{array}{l}\text { Employees, } \\
\text { managers and } \\
\text { customers }\end{array}$ & $\begin{array}{l}\text { Followers } \\
\text {-business } \\
\text { people }\end{array}$ \\
\hline
\end{tabular}

Source: own work.

\section{Conclusions}

The roles very often combine with each other. Researchers become academic teachers and some can also be regarded as 'management gurus'. The division can be seen as indistinct. A researcher may have a very specific work which can end in individual solutions without any place for generalisation or on the opposite - he might work on a general research with no connotations with practice. Management researchers often work in other fields, such as economy, 
organizational sociology or anthropology. The dominant view of management scholars is that there is a necessity of intervention and dialogue between academic and managerial world [Abrahamson, Eisenman 2001, pp. 67-76].

The analysis suggests that academic teacher and researcher are social roles with a character that can be called universal. Practitioner is more connected with pragmatic aspect of management science. Practitioners are often regarded as managers, but their roles in the organisation might as well be non-managerial [Sułkowski 2013, ch. 5].

\section{References}

Abrahamson E., Eisenman M. (2001), Why management scholars must intervene strategically in the management knowledge market, "Human Relations", 54.1, New York, pp. 67-76.

Burrell G., Morgan G. (1979), Sociological Paradigms and Organisational Analysis, Heinemann, London.

Duncan W.J. (1974), Transferring management theory to practice, "Academy of Management Journal", 17.4, pp. 724-738.

Figiel S. (2006), Problem poznania naukowego w marketingu, w: Ekspansja czy regres marketingu, ed. E. Duliniec, L. Garbarski, J. Mazur, M. Strzyżewska, W. Wrzosek, PWE, Warszawa, p. 36.

Ghoshal S. (2005), Bad management theories are destroying good management practices, "Academy of Management Learning \& Education", 4.1, pp. 75-91.

Gummson E. (1991), Qualitative methods in management research, Newbury Park, Calif.: Sage Publications, p. 39.

Hatch M.J. (2002), Teoria organizacji, PWN, Warszawa.

Micklethwait J., Wooldridge A. (1998), The witch doctors: making sense of the management gurus, Times Business, pp. 19-20.

Peters T. (1994), The Tom Peters Seminar. Crazy Times Call for Crazy Organisations, MacMillan, London.

Strang D., Macy M.W. (2001), In Search of Excellence: Fads, Success Stories, and Adaptive Emulation, "American Journal of Sociology", July, Vol. 107, No. 1, pp. 147-182.

Sułkowski Ł. (2012), Epistemologia i metodologia zarządzania, PWE, Warszawa, pp. 13-23.

Sułkowski Ł. (2013), Epistemology of Management, Peter Lang International, Frankfurt-Berlin-Bern-Vien-Oxford-New York-London-Warsaw, ch. 5. 
Sułkowski Ł. (2006), Nurt krytyczny w naukach o zarządzaniu, „Współczesne Zarządzanie", nr 1.

Tranfield, D., Starkey K. (1998), The nature, social organization and promotion of management research: towards policy, "British Journal of Management", 9.4, pp. 341-353.

Znaniecki F. (1984), Spoteczne role uczonych, Państwowe Wydawnictwo Naukowe, Warszawa. 